\title{
A Contrastive Analysis of English and Albanian Somatic Idioms - A Cognitive Perspective
}

\author{
Arben Gaba \\ "Eqrem Çabej” University, Faculty of Education and Social \\ Sciences, Department of Foreign Languages, English Branch
}

\section{Abstract}

In this paper we try to make a cognitive comparison between phraseological expressions originating from body-part terms in English and Albanian (taking English as our starting point). Although these languages are distant in space they do have similarities. This similarity / difference is seen better than nowhere else in the way how they conceive of the world (and the way this is expressed linguistically). They are at different stages of their linguistic cultivation where English is in a dominant position (remember here that every technological innovation has knock-on linguistic effects that affect every language including Albanian) and Albanian is in a defensive position since it has to cope with a host of concepts and realities that in one way or another have to be made tangible to Albanian speakers as well. Phraseological expressions are conceived as the tip of the iceberg of a process grounded upon transformational mechanisms (the best known of which are metaphors and metonymy) with emotional coloring adding to the mix. By way of illustration we give the following example: get blood from/out of a stone - nxjerr dhjamë nga pleshti, nxjerr ujë nga guri (extract fat out of a flea, extract water from the stone) Albanian literal translation in italics and brackets. From what we see, Albanians associate the equivalent of the English phraseological unit with water (since they are a Mediterranean country with dry summers), or with fat and flea (Albanians are known for their animal husbandry and meat-related terms).

Keywords: somatic idiom, cognition, metaphor, English, Albanian, culture

\section{Introduction}

A unique tool that we have at their disposal and that enables us to interact with other people and get our message across, is without doubt our ability to utter words, i.e. language. By default, we use language to express ourselves and respond to various situations in uniquely infinite and creative ways, but we are also economical in our use of language, i.e. whenever we find ourselves in situations that follow a certain 
pattern our linguistic response acts accordingly. In such cases our language production ability avails itself of "ready-made" or "prefabricated" word combinations (of different kinds) which are stored in our brains and used whenever the need arises. In fact, these "prefabricated" word combinations make up a large part of our language (this is true, to varying degrees, of all the languages spoken around the world) and estimates go as high as $80 \%$ (Nattinger 1988: 76). So, even though at first we would think that we speak in words and such ready-made word combinations merely ornament or embellish our language "Rather than being peripheral to the 'core' of a language, it is possible to argue that such idiomatic expressions are the core (Taylor 2002: 541). This goes to show that when speak we do not start from scratch every time but rely on these "ready-made" word combinations. One thing that such combinations have in common is the fact that their meaning cannot be inferred from individual words but rather they have a global meaning with varying degrees of motivation.

When it comes to categorizing them or giving them names, opinions differ and there is a multitude of designations which still in use today. Some of them are 'phraseological units', 'word-combinations', and 'phrasal lexemes' (Cowie 1998:1), to name but a few. This plenitude of designations owes its existence to many factors and it is not the aim of this paper to provide a detailed explanation of each and every one of them due to limitations of space. To attest to their complicated nature and why it has proven so difficult to come up with clear-cut categories we would like to mention the fact that many scholars have attempted this task based on different criteria and the issue is far from settled. The Russian tradition, with such representatives as Vinogradov, Amosova, Koonin, Arnold, has been very influential in this field and has inspired other Western scholars primarily because "Its principal legacy is a framework of descriptive categories that is comprehensive, systematic, and soundly based." (Cowie 1998: 4). One such scholar that has been influential because of its categorization principles is Vinogradov. He categorized such word combinations according to the semantic principle. "Within the general class of nominations (for which he used the term 'phraseological unit'), Vinogradov ( 1947) drew a distinction between 'phraseological fusions' (also called 'idioms'), 'phraseological unities', and 'phraseological combinations'." (Cowie 1998: 4-5). Now, of course, their degree of motivation of meaning is also different ranging from the least motivated ones the 'phraseological fusions' where we can mention neck and crop-altogether, entirely; 'phraseological unities' where the meaning of the whole can be guessed from the meanings of its components, but it is transferred (metaphorically or metonymically), for example, to lose one's head - to be at a loss what to do/to be out of one's mind; to show one's teeth- to show that you are angry; 'phraseological combination' units consisting of two open-class words, such as meet the demand, they have one component used in a literal sense, and the other is used figuratively. So, as see the degree of semantic transparency or a lack of it serves as 
a kind of linguistic common denominator or unifying theme of phraseological units including idioms.

As regards the issue of motivation of idioms we want to say that there are two views. The traditional view according to which "all there is to idioms is that, similar to words, they have certain syntactic properties and have a meaning that is special, relative to the meanings of the forms that comprise it" KÖVECSES (2010:231). And the Cognitive Linguistic View acording to which "Many, or perhaps most, idioms are products of our conceptual system and not simply a matter of language (i.e., a matter of the lexicon). An idiom is not just an expression that has a meaning that is somehow special in relation to the meanings of its constituting parts, but it arises from our more general knowledge of the world embodied in our conceptual system. In other words, idioms (or, at least, the majority of them) are conceptual, and not linguistic, in nature." KÖVECSES (2010: 233). Here we see fit to give some context regarding the use of the term somatic idiom or somatism. First, we would like to say that the word 'soma' comes from Greek meaning 'body'. Estonian scholar F. Vack was the first who introduced the term "somatic" to linguistics. Researchers frequently make use of this term when they want to talk about body-part term idioms. Among such reseachers we can mention F. Cermák (1998: 109-119) with his article "Somatic Idioms Revisited", Sabina HALUPKA-REŠETAR, Edit ANDRIĆ with their article "Somatisms with the Lexeme Láb in Hungarian, Noga in Serbian and Leg/ Foot in English" (2016: 21-34), etc,.

The framework upon which the analysis of the somatic idioms in these two languages rests has been developed by George Lakoff and Mark Johnson in their groundbreaking study Metaphors We Live By (George Lakoff and Mark Johnson 1980). In it they claim and show that contrary to being a property of the lexicon and poets and writers, metaphor (in all its manifestations) is wired into our brains as part of our (linguistic) evolutionary journey. This has profound implications when it comes to idioms as they are the most colourful and vibrant part of our vocabulary and motivated in large part by metaphors. However, idioms as we will try to show are not only motivated by conceptual metaphors but also by conventional knowledge and conceptual metonymy (more on these later).

Our sample contains 4 body parts, the eye, the nose, the heart, and the hand. First we give the English idiom followed by the Albanian equivalent and then the Albanian literal translation in brackets, all idiomatic expressions are given in italics, nonidiomatic ones in normal and body-part terms are in bold face. Now, of course we will not analyse each and every one of these idiomatic expressions one by one (maybe this is the topic of another paper) we will limit ourseves to some of them just to give an idea of the cognitive mechanisms behind their motivation. Here is our small corpus:

bad/poor hand at sth -dorëngathët, s'i vjen ndoresh (clumsy-handed, not to be good at) 
force sb's hand - detyroj (shtrëngoj) dikë të veprojë pa dëshirë (force sb to act without will)

bite the hand that feeds one -shkel bukën me këmbë (trample the bread under the feet) lend sb a (helping) hand with sth - jap një dorë (give a hand)

keep a tight hand/rein on sb-mbaj nën kontroll (keep under control) cap in hand - me nderim, plot respekt (përulje, përunjësi) (with reverence, full of respect, humility)

hat in hand -gjithë servilizëm (përulësi, temena) (full of obsequiousness)

play into sb's hands - bëj lojën e dikujt, çoj ujë në mullirin e dikujt (make sb's game; take water into sb's mill)

bind sb hand and foot - lidh këmbë e duar (bind feet and hands)

catch sb red-handed - kap me presh në dorë (catch with leeks in the hand)

at first hand - drejtpërdrejt, nga burime të drejtpërdrejt (directly, from direct sources)

take one's courage in both hands -marr zemër (take heart)

take matters into one's own hands - i marr vetë punët në dorë (take myself matters in hand)

Rub your hands- fërkon duart (rubs the hands)

Hand in glove- si mishi me thuan (like the flesh with the nail)

Out of hand-jashtë kontrollit (out of control)

Someone's right hand- dora e djathtë (right hand)

The upper | whip hand - the position of power or control- pozita dominuese (dominant position)

Wait on hand and foot- i shërbej me të gjitha mënyrat (serve with all the ways)

Someone's hands are tied-i ka duar të lidhura (has hands bound)

Have one's hands full- jam i zënë (I am busy)

Out of someone's hands- out of or beyond someone's control: jashtë kontrollit të (out of the control of)

Sit on one's hands - lidh (kryqëzon) duart (ties (crosses) the hands)

Cross someone's palm |hand with silver-i ka lyer rrotën (dorën) dikujt (has greased the wheel (the hand) $s b$ )

have an eye for - ka ndjenjën e, ia thotë për ( has the sense of, is good at) 
all ears/eyes -gjithë, tërë sy e veshë (all eyes and ears) apple of one's eye -drita e syve (the light of the eyes) close one's eyes to - mbyll sytë para (close the eyes in front of) turn a blind eye to sth -bëj një sy qorr (make a blind eye) catch sb's eye -shihem sy më sy, kryqëzoj shikimin (look eye to eye, cross the look) feast one's eyes on - kullot sytë (graze the eyes on) believe one's ears / eyes - u besoj veshëve (syve) (believe the ears, eyes) do sb in the eye - i'a hedh sy për sy (deceive sb, cast it eye to eye) cry one's eyes out - shkrihem së qari, shkrihem në lot (melt while crying, melt in tears) cast an eye/one's eye(s) over sb/sth - hedh një sy (cast an eye)

Out of the corner of one's eye - me bisht të syrit (with the tail of the eye) Not bat an eyelid|eye- nuk i trembet syri (the eye is not scared) Cannot take one's eyes off - mu bë syri gozhdë (the eye turned into nail) With one's eyes closed - me sy mbyllur (with closed eyes) Remove the scales from one's eyes- $i$ hapi sytë (opened his/her eyes) In the twinkling of an eye- sa hap e mbyll sytë (how open and close eyes) Keep a lone's weather eye open-i bëj sytë katër (make the eyes four) Pull the wool over someone's eyes- $i$ hedh hi syve (cast his / her ashes at the eyes) cut off one's nose to spite one's face - në vend që t'i vinte vetulla, i nxori sytë (instead of putting him/ her eyebrows, gouged his/ her eyes out)

blow one's nose - shfryj hundët (blow the noses) keep one's nose to the grindstone -punoj pa pushim (work tirelessly) Plain as the nose on your face- shumë e qartë (very obvious) One's nose is in the air-me hundën përpjetë sillem mendjemadh (with the nose up) bloody someone's nose- $\mathrm{i}$ ra hunda (his /her nose fell) follow one's nose- eci drejt (walk stright) have a nose for- ia zë hunda (his/her nose catches it) (always) have one's nose in a book- lexues i apasionuar (avid reader) Keep one's nose clean- qëndroj larg telasheve (stay away from trouble) Lead by the nose- tërheq për hunde (lead by the nose) 
Look down one's nose- $e$ sheh nën hundë dikë, e sheh me përçmim (look at under the nose, look scornfully)

On the nose - egzaktësisht (exactly)

Pay through the nose- paguaj shtrenjtë (pay dearly)

Poke|push|stick one's nose into- fus hundët në (put the noses in)

Put someone's nose out of joint- ofendoj dikë (offend someone)

(Right) under someone's (very) nose- hundë më hundë (nose to nose)

(Right) under someone's (very) nose-përpara hundës (in front of the nose)

Be no skin off someone's nose - not to be someone's concern, responsibility, etc - shih punën tënde (mind your own business)

break one's heart - i'a thyej zemrën dikujt (break his/ her heart)

hand over heart -me dorë në zemër, çiltërsisht, ndershmërisht (with hand on the heart, frankly, honestly)

take heart - marr zemër (take heart)

after one's own heart- si ma do zemra (as my heart likes it)

have a corner in sb's heart -ruaj të gjallë në zemër (save alive in the heart)

cry one's heart out - qaj me ngashërim (sob)

eat one's heart out -ligështohem, ha veten përbrenda, vuaj përbrenda (droop, suffer from the inside, eat myself from the inside)

have a heart -tregoj mëshirë (show mercy)

have a heart of gold -e ka zemrën flori (he /she has the heart gold)

have a heart of stone -e ka zemrën gur (he/she has the heart stone)

pluck up (one's) heart - marr zemër, bëhem trim (take heart, become brave)

a change of heart -ndryshim në qëndrim, në gjendjen shpirtërore (change in attitude, in state of mind)

From the bottom of one's heart - nga fundi i zemrës (from the end of the heart)

Can find it in one's heart- to be ready or willing (to do smth): më bën zemra (the heart does)

Have one's heart in one's mouth - i shkoi (i ra) zemra te thembra (his /her heart fell on the heel)

Put one's heart and soul into- - me mish e me shpirt (with flesh and soul)

Have one's heart in one's boots - me zemër të dridhur (with shaky heart) 


\section{Pull|tug at |one the |someone's heartstrings - më dhemb zemra (my heart aches)}

Before venturing the analysis of the somatic idioms we would like to elaborate a bit (at the same time try to be concise) on these cognitive mechanisms underlying them. First we start with metaphor "In the cognitive linguistic view, metaphor is defined as understanding one conceptual domain in terms of another conceptual domain.... A conceptual metaphor consists of two conceptual domains, in which one domain is understood in terms of another" KÖVECSES (2010: 4). The two domains which interact or rather the two halves of a conceptual metaphor are respectively called source domain and target domain. The conceptual domain which helps us understand the other conceptual domain is the source domain, this is usually more concrete while the conceptual domain that is understood through it is the target domain, and this is usually more abstract.

Since in our daily practices we find ourselves in different situations we might have to provide information related to space, existence or other dimensions so the metaphors we use also have to be used accordingly. Thus, conceptual metaphors are further subdivided into: structural, ontological, and orientational. However, despite the kind of metaphor we are dealing one crucial element pertaining to them and unites them all is mappings or systematic correspondences, these enable the transfer of meaning from one domain to the other and help us gain an insight into what has motivated the relationship between the respective part of the body and the situation.

However, most of the time, idioms have more than one basis or motivation underlying them, other such motivations are respectively metonymy and conventional knowledge. Differently from metaphor, metonymy is a relationship of the type in which one kind of entity "stands for" another kind of entity or one thing. Unlike the metaphor a metonymy is made up of a vehicle and a target. And unlike metaphor which is a matter of similarity, metonymy deals with contiguity and they vary from culture to culture as Niemeier (1998: 123) says "the conceptual contiguity of metonymy is based on extralinguistic experiences and connotations and is therefore culture-dependent". "It is a basic feature of metonymically related vehicle and target entities that they are "close" to each other in conceptual space" KÖVECSES (2010: 173). Metaphor and metonymy are theoretically clearly distinct from one another but in reality it is quite difficult to distinguish between them. A good rule of thumb to keep in mind when we are faced with them is to apply the "is like" test proposed by Ray Gibbs (1994) KÖVECSES (2010: 174), in fact sometimes they are so intertwined that Goosens $(1990 ; 2000)$ claims "that there is not always a clear demarcation between metaphor and metonymy. Some figurative items could be both a metaphor or metonym according to the context so that the two concepts may then become intertwined. This has led to the coining of a new term metaphtonymy, i.e. metaphor and metonymy being interwoven". 
And the third motivation is conventional knowledge. Simply put it is the totality of our ideas, beliefs, fears, hopes, and patterns, i.e. basically all the information that we possess about the world around us. It is inherent in all of us and permeates every domain of our existence and we make use of it unconsciously, i.e. whenever we use an idiom grouded in conventional knowledge we take it for granted that the people we are talking to already know what we are talking about.

Let us illustrate the interaction of the abovementioned motivations by analysing the idiom: keep a tight hand/rein on sb which means keep under control we see that hand stands for control so as we said if something stands for something else and based on what we said previously, we would obviously treat this as a case of metonymy, but this is not the only lexical unit participating in the sentence. So we turn to the other lexical unit tight, now going by the dictionary we know that tight means fixed, fastened, closed firmly; hard to move, undo or open and conventional knowledge tells us that if we keep something tight it does not go away so by combining these two motivations we have the final idiom. Now, as we saw the Albanian equivalent $m b a j$ nën kontroll (keep under control) does not involve the word hand at all, the reason for this according to our interpretation as a native Albanian is that Albanians do not see a connection between the body-part hand and control, as we mentioned before different peoples decode the world around us in different ways.

Let us analyse another idiom catch sb's eye whose real meaning is to attract someone's attention. First we know that if we are looking at someone or something (as a prerequisite we have to use our eyes) we direct our gaze towards someone or something an implied element is that we do this while paying attention, so eye stands for attention and catch is a substitute for attract, so we see that the motivation underlying this is metonymy. The Albanian equivalent on the other hand is -shihem sy më sy, kryqëzoj shikimin (look eye to eye, cross the look) and it is not a idiom, again we see that there is a difference in the way we think.

Our next idiom is One's nose is in the air meaning one is acting conceited or aloof - the first layer of this idiom is conventional knowledge which in this case tell us that one of the tell-tale signs regarding someone's bearing is the parts of the body which are the most noticeable ones, hence the position of the nose, here we move to idea of active zone (LANGACKER, R.W. 1984) moving further into the convoluted reality of meaning we say that nose stands for bearing. Another layer would be being in the air is being excessively proud of oneself so here we are dealing with a metaphor, because as we said "Metaphor allows people to understand one thing as another, without thinking the two things are objectively the same" Sweetser (1990: 8) thus we have a combination of the three cognitive devices contributing to the global meaning of the idiom. The Albanian equivalent is me hundën përpjetë (with the nose up). So, this is one of those cases in which the way peoples think coincides. 


\section{Conclusions}

Contrary to being on the periphery of the language idioms are central to the way we think and speak. They enrich our language, make it more colourful and vivacity. They are woven into the very fabric of our language, in the way we try to interpret reality, try to digest it and store it into our minds. Such a linguistic feat cannot be pulled off without the mental machinery wired inside our brain and more precisely the active participation of finer cognitive devices which construe, process and interpret this interaction, sometimes alone sometimes in close cooperation with each other. As we saw from our sample (almost 80 idioms) both languages are highy idiomatic but English expresses itself more idiomatically than Albanian, a possible explanation for this would be that where English comes into contact with a situation where our cognitive devices are triggered the outcome is an idiom which makes a dent in the mental lexicon and this is repeated whenever a similar situation occurs, this apparently does not happen in Albanian.

\section{References}

[1] Nattinger, J.R. (1988). Some Current Trends in Vocabulary Teaching, in R. Carter and M. McCarthy (eds.) Vocabulary and Language Teaching, London: Longman, pp. 62-82.

[2] Phraseology, Theory, Analysis, and Applications Edited by A. P. Cowie Clarendon Press. Oxford 1998

[3] Kövecses, Z (2010). Metaphor, A Practical Introduction, Second Edition. Oxford University Press

[4] Čermák F. 'Somatic Idioms revisited.' In W. Eismann (ed.), Europhras 95 Europäische Phraseologie im Vergleich: Gemeinsames Erbe - 1998, und kulturelle Vielfalt. Bochum: Universitätsverlag Dr. N. Brockmeyer (= Studien zur Phraseologie und Parömiologie, 15), - 109-119.

[5] Sabina Halupka-Rešetar, Edit Andrić "Somatisms with the Lexeme Láb in Hungarian, Noga in Serbian and Leg/ Foot in English" De Gruyter Open, Acta Universitatis Sapientiae, Philologica, 8, 2, (2016) 21-34.

[6] George Lakoff and Mark Johnson (1980). Metaphors we live by. The University of Chicago Press

[7] Ilo Stefanllari, English-Albanian Dictionary of Idioms, Hippocrene Books, Inc. New York, 2000

[8] Thomai, J.(1999). Fjalor frazeologjik $i$ gjuhës shqipe. Shtëpia Botuese "Shkenca",Tiranë.

[9] Thesaurus of Traditional English Metaphors Second edition P.R.Wilkinson, 2002

[10] Longman Dictionary of English Idioms, Longman group limited 1979

[11] Oxford Dictionary of Idioms, edited by Judith Siefring, Oxford University Press, 1999 
[12] Milkov, N. (2000). 'Logico-Linguistic Moleculism: Towards an Ontology of Collocations and Other Language Patterns', in K. I. Simov and A. Kyriakov (eds.) Ontologies and Lexical Knowledge Bases, Proceedings of OntoLex 2000, Sozopol, Bulgaria, pp. 82-94.

[13] Taylor, J.R. (2002). Cognitive Grammar. Oxford: Oxford University Press.

[14] Langacker, R.W. 1984. Active zones. Proceedings of the Annual Meeting of the Berkeley

[15] Linguistic Society, vol. 10, 172-188.

[16] Sweetser, Eve (1990): From Etymology to Pragmatics: Metaphorical and Cultural Aspects of Semantic Structure, Cambridge, Cambridge University Press.

[17] Goosens, L. (1990), 'Metaphtonomy: the interaction of metaphor and metonymy in expressions for linguistic action', Cognitive Linguistics, I (3): 323-40 (2000), 'Patterns of meaning extension, "parallel chaining", subjectification and modal shifts', in Barcelona (2000), pp. 149-69.

[18] Niemeier, S. 1998. Colourless Green Ideas Metonymise Furiously. In Ungerer, F. (ed.), Kognitive Lexikologie und Syntax. Rostock: Universität Rostock (Rostocker Beiträge zur Sprachwissenschaft: 5, 119-146. 